\title{
The effect of covering and mulching on the soil temperature, growth and yield of tomato
}

Edyta Kosterna

\author{
Department of Vegetables \\ Siedlce University of Natural Sciences and Humanities \\ B. Prusa 14, 08-110 Siedlce, Poland
}

\begin{abstract}
By improving the thermal and moisture conditions in the immediate vicinity of plants, plastic covers influenced the growth and development and increased the yield of vegetables. Soil mulching with organic material is one method of soil water protection and also helps maintain a constant soil temperature within the root system of crops. This study investigated the effect of plant covering and the type of straw applied to soil mulching (rye, corn, rape or buckwheat) on the soil temperature, development of the plant and the yield of 'Polfast' $F_{1}$ tomato. The effect of the straw was compared to a control plot without mulch. Soil temperature at a depth of $10 \mathrm{~cm}$ was higher in covered plots than in the plot without covers. The increase in soil temperature as a result of covering amounted to $1.3^{\circ} \mathrm{C}$ at $8: 00 \mathrm{a} . \mathrm{m}$. and $1.7^{\circ} \mathrm{C}$ at 2:00 p.m. Both in the morning and in the afternoon, the soil temperature in the plots without straw and without covers and under polypropylene fibre was higher than in the plots with straw. The application of covers resulted in higher aboveground parts of plants and higher leaf area compared to cultivation without covers. Irrespective of whether a covering was used, all of the types of straw investigated in the experiment caused the acceleration of growth and development of tomato plants. Simultaneous plant covering and soil mulching increased the total yield of fruits but did not have an influence on the share of marketable yield of the total yield.
\end{abstract}

Key words: assimilation leaf area, cover, leaf area index (LAI), Lycopersicon esculentum L., mulch, specific leaf area (SLA)

\section{INTRODUCTION}

The yield of tomato depended to a higher degree on the weather conditions, in particular the air temperature, during the initial period of plant growth. By improving the thermal and moisture conditions in the immediate vicinity of the plants, plastic covers influenced their growth and development and increased the yield of vegetables. Plants grown under polypropylene fibre have more uniformity, are taller, and are also characterised by a larger mass of aboveground parts as compared to cultivation without covers (Ibarra et al. 2001, Gimenez et al. 2002, Wadas et al. 2009). Earlier plant development under covers allows for greater solar radiation interception and the enlargement of the assimilation leaf area, which has the greatest impact on plant productivity (Soltani et al. 1995, Kołodziejczyk 2012).

Soil mulching with organic material is one method of soil water protection and also helps maintain a constant soil temperature within the root 
system of crops (Awal and Khan 2000, Sinkevičienè et al. 2009, Samaila et al. 2011). This is very important for thermophilic plants, because mulch, by maintaining proper moisture and decreasing soil warming in summer months as well as reducing daily temperature fluctuations, improves soil conditions for plant growth and development. A favourable effect of soil mulching on the growth and development of plants and increased vegetable yield was found by Teasdale and Abdul-Baki (1997) in tomato, Awal and Khan (2000) in maize as well as Soltani et al. (1995) and Ibarra et al. (2001) in melon. The current research shows that the most commonly used organic mulch is rye straw. There is a scarcity of reports regarding the possibility of applying straw of different types of species.

This study aimed to determine the effect of covering plants with polypropylene fibre and soil mulching using different types of straw on changes in soil temperature and the growth and development of plants and the resulting yield level of tomato cultivated in the field.

\section{MATERIAL AND METHODS}

The experiment was carried out in the years 20102012 at the Experimental Station of the Siedlce University of Natural Sciences and Humanities, which is located in central-eastern Poland $\left(52^{\circ} 03^{\prime} \mathrm{N}\right.$, $\left.22^{\circ} 33^{\prime} \mathrm{E}\right), 115 \mathrm{~km}$ east of Warsaw. According to the international system of FAO classification, the soil was classified as a Luvisol (LV) (WRB FAO 1998). The soil organic matter content averaged $1.5 \%$ and its humus horizon reached a depth of 30-40 cm. The content of plant available nutrients is presented in Table 1.

The experiment was established as a split-block design with three replicates. The effect of plant covering (not covered, under covers) and the type of straw applied to soil mulching (rye, corn, rape or buckwheat) on the soil temperature, development of plant and yield of 'Polfast' $F_{1}$ tomato was investigated. The effect of the straw was compared to a control plot without mulch.
The reason for selecting this cultivar was because it is early and also useful for cultivation in the open field. 'Polfast' $F_{1}$ tomato is characterised as having an average fruit mass that is of very good quality, and as having a high content of dry matter and extract. This cultivar produces a high yield even in low air temperatures. It is also more resistant to diseases compared to other tomato cultivars.

The forecrop was triticale. In the autumn preceding tomato cultivation, ploughing was performed. At the same time, farmyard manure was incorporated at a rate of $30 \mathrm{t} \mathrm{ha}^{-1}$. In the spring, two weeks before the seedlings were planted, disc harrowing was applied to loosen the upper soil layer and prepare it for planting. After that, mineral fertilisers were applied in the amount of supplementary content to the optimal level for tomato: $85 \mathrm{~kg} \mathrm{~N}, 104 \mathrm{P}_{2} \mathrm{O}_{5}, 234 \mathrm{~K}_{2} \mathrm{O}$ per 1 ha. Mineral fertilisers were applied in the form of ammonium nitrate, triple superphosphate and 60\% potassium salt.

Before planting seedlings, individual types of straw at a dose of $10 \mathrm{t} \mathrm{ha}^{-1}$ were applied. The thickness of the mulch layer depended on the type of mulch. In the case of rye and rape straw, the thickness of the mulch layer amounted to $7-8 \mathrm{~cm}$ on average; in the case of corn straw the mulch layer amounted to about $5 \mathrm{~cm}$, however for buckwheat straw it was $8-10 \mathrm{~cm}$ on average.

Tomato seedlings were grown in a heated greenhouse. The seeds were sown to seedling containers with peat substrate on 18 March in 2010 and 2011 and 28 March in 2012. After cotyledon formed and at the beginning of first leaf emergence, the seedlings were bedded into pots with a diameter of 8-10 cm (1 April in 2010 and 2011 and 11 April in 2012). Prior to transplanting the seedlings were hardened off and then moved permanently outdoors. Plants were planted on 20,16 and 14 May in the successive study years, at a spacing of 60 $\times 40 \mathrm{~cm} .18$ plants were planted in each plot.

Directly after the seedlings were planted, suitable combinations were covered with Pegas Agro 17UV polypropylene fibre. The cover was

Table 1. Characteristics of soil conditions before experiment placing (available food component contents)

\begin{tabular}{|c|c|c|c|c|c|c|c|c|}
\hline \multirow{2}{*}{ Years } & \multirow{2}{*}{$\mathrm{pH}$} & \multirow{2}{*}{ C-org. $\%$} & $\mathrm{~N}-\mathrm{NO}_{3}$ & $\mathrm{~N}-\mathrm{NH}_{4}$ & $\mathrm{P}$ & $\mathrm{K}$ & $\mathrm{Ca}$ & $\mathrm{Mg}$ \\
\hline & & & \multicolumn{6}{|c|}{$\mathrm{mg} \mathrm{dm}^{-3}$ air dry mass } \\
\hline 2010 & 5.7 & 1.7 & 8 & 7 & 32 & 70 & 220 & 24 \\
\hline 2011 & 5.4 & 1.6 & 22 & 9 & 44 & 108 & 340 & 47 \\
\hline 2012 & 5.0 & 1.3 & 13 & 6 & 27 & 70 & 220 & 37 \\
\hline Mean & 5.4 & 1.5 & 14 & 7 & 34 & 83 & 260 & 36 \\
\hline
\end{tabular}




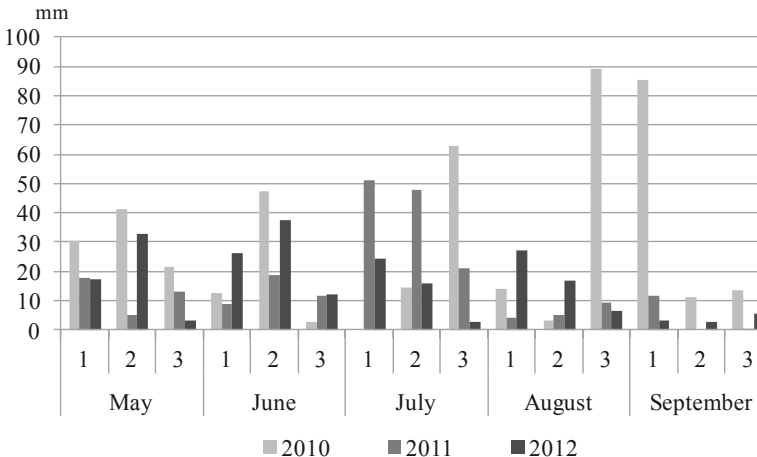

Figure 1. Weather conditions in the years of the study

removed after three weeks. After that, $50 \mathrm{~kg} \mathrm{~N}$ ha $^{-1}$ in the form of ammonium nitrate was applied (top dressing). During the growing season, systematic tomato plant protection against fungal diseases was carried out. At 10-day intervals, the following plant protection sprays were applied: Infinito 687.5 SC (propamocarb hydrochloride - $625 \mathrm{~g}$ and fluopicolide - 62.5 g), Amistar 250 SC (azoxystrobin - $250 \mathrm{~g}$ ) and Ridomil Gold ${ }^{\circledR}$ MZ Pepite 67.8 WG (mancozeb - 64\% and metalaxyl-M-3.8\%).

During the plant growing period, measurement of the soil temperature was performed at a depth of $10 \mathrm{~cm}$ for all objects, at 8:00 a.m. and 2:00 p.m.

Tomato fruit harvesting was performed several times as the fruit ripened. Immediately before first harvest (third 10-days of July) the height of plants, mass of plants, assimilation leaf area, leaf area index (LAI) and specific leaf area (SLA) were determined. The measurements were performed on four successive plants per plot. The assimilation leaf area was measured by the weight method (Roztropowicz 1999). The beginning of harvest occurred in the last 10 days of July and ended in the first 10 days of September. During the harvest the total yield of tomato fruits was determined.

The results of the experiment were statistically analysed by means of the analysis of variance following the mathematical model for the splitblock design. Significance of differences was determined by the Tukey test at the significance level of $\alpha=0.05$.

Weather conditions in the years of the study were varied (Fig. 1). 2010 was characterised by rather high air temperatures but also more moisture compared to the following years of the study, in particular during the final period of plant growth. However, a shortage of rainfall in the last 10 days of June and at the beginning of July contributed to the weaker growth of plants. In turn, a higher rainfall at the end of August and at the beginning

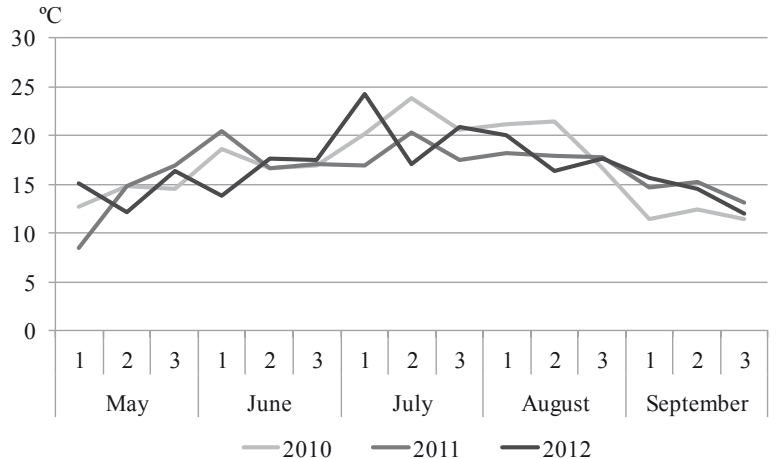

of September favoured fungal diseases. 2011 was characterised by high and similar air temperature from the planting time to the beginning of harvest. Insufficiency of water in June, especially in the first 10 days, was compensated for by heavy rainfall in July. A lower rainfall at the end of the vegetation period was profitable to fruits maturing. Mean air temperatures in 2012 were high, with only a slight fall in the temperature in the first 10 days of June. The drought in the last 10 days of May (after seedling planting) had no influence on the growth of plants. June, July and August were characterised by quite regular rainfall distribution.

\section{RESULTS AND DISCUSSION}

Covers reduce evaporation and decrease heat losses at night, allowing better plant growth as a result (Winiarska 2006), which was confirmed in the present study. Soil temperature at a depth of $10 \mathrm{~cm}$ in covered plots was higher than in plots without covers (Fig. 2). The increase in soil temperature as a result of covering amounted to $1.3^{\circ} \mathrm{C}$ at $8: 00$ a.m. and $1.7^{\circ} \mathrm{C}$ at 2:00 p.m. The highest influence of covers on soil temperature increase was observed in the last week of May. In this period the differences between plots without covers and those with polypropylene fibre covers amounted to up to $1.7^{\circ} \mathrm{C}$ at measurements taken at 8:00 a.m. and $2.6^{\circ} \mathrm{C}$ at measurements taken at 2:00 p.m. In the study by Moreno et al. (2002), the soil temperature at a depth of $5 \mathrm{~cm}$ was higher under a nonwoven polypropylene sheet by $5^{\circ} \mathrm{C}$ on average. In the study by Hamouz et al. (2006), plant covering with polypropylene fibre contributed to an increase in soil temperature of $1.8^{\circ} \mathrm{C}$ on average and of $2.0^{\circ} \mathrm{C}$ in air temperature.

Both in the morning (measurement at 8:00 a.m.) and in the afternoon (measurement at 2:00 p.m.) the soil temperature in the plots without straw without 

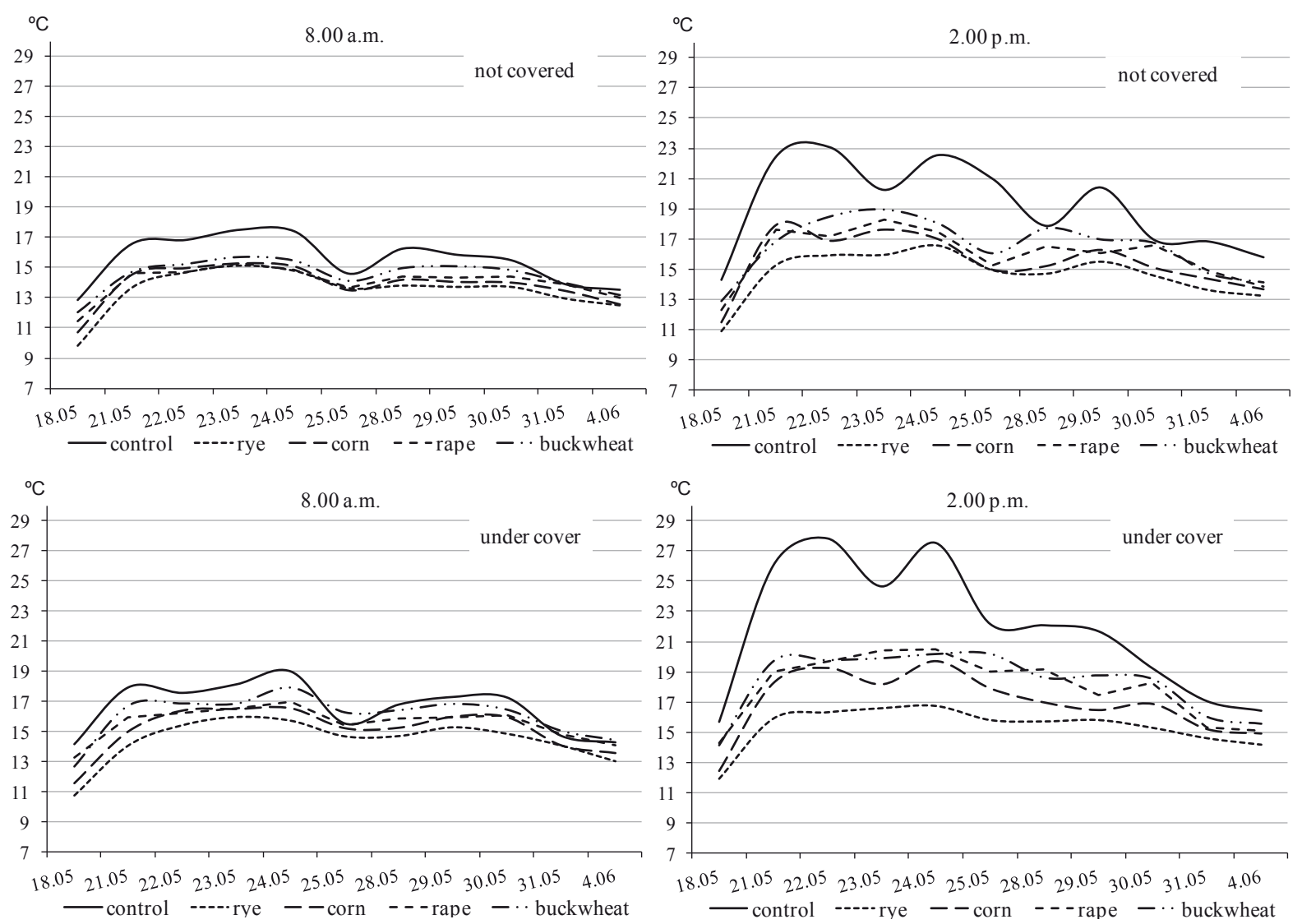

Figure 2. Soil temperature $\left({ }^{\circ} \mathrm{C}\right)$ at a depth of $10 \mathrm{~cm}$ on different types of straw measured at 8:00 a.m. and 2:00 p.m.

covers and under polypropylene fibre was higher than in the plots with straw (Fig. 2). The lowest fall in temperature compared to the control plot was observed in plots mulched with buckwheat straw. In the plots without covers, reductions in soil temperature as a result of buckwheat straw mulching amounted to $1.1^{\circ} \mathrm{C}$ at $8: 00$ a.m. and $2.8^{\circ} \mathrm{C}$ at 2:00 p.m., and in covered plots the differences amounted to 0.6 and $3.5^{\circ} \mathrm{C}$, respectively. The cause of the smaller differences in soil temperature may be the darker colour of the straw. Because of its darker colour, buckwheat straw absorbs more sunlight than other types of straw. The highest fall in soil temperature as a result of mulching was found in plots with rye straw. Irrespective of covering, the reductions in soil temperature in the morning amounted to $2.1^{\circ} \mathrm{C}$, and in the afternoon were up to $5.5^{\circ} \mathrm{C}$. It was also found that mulching soil resulted in not only lower temperatures, but their fluctuations were also lower compared to plots without straw, particular during measurements at 2:00 p.m. This was confirmed in studies by Chakraborty et al. (2008), in which soil temperature mulched with rice straw was lower at a depth of 7 and $14 \mathrm{~cm}$ during all growing periods, especially during measurements in the afternoon hours. In the study by Sinkevičienè et al. (2009), all organic mulches caused a significant reduction of soil temperature. The highest differences, ranging from $0.7^{\circ} \mathrm{C}$ to $1.6^{\circ} \mathrm{C}$, were observed between the control object without mulch and plots mulched with straw. According to many authors, a slower increase in soil temperature under mulches and also lower fluctuations of soil temperature in the plant growing period contribute to the better growth and development of plants (Schonbeck and Evanylo 1998, Olasantan 1999, Kęsik and Maskalaniec 2005, Dahiya et al. 2007, Sinkevičienè et al. 2009). In turn, some authors claim that natural organic mulch eventually breaks down and becomes a part of the soil and a source of plant nutrients (Bond and Grundy 2001, Gruber et al. 2008), which as a result improve plant growing conditions.

The effect of covering and the type of straw applied to soil mulching on plant height was statistically confirmed (Tab. 2). In the combination with polypropylene fibre, the plants cultivated on mulches with corn, rape and buckwheat straw were higher compared to the control without mulching. It was also found that cultivation on corn and rape straw contributed to an increased height of plants compared to rye straw. Similarly, in the studies by Sajid et al. (2013), pea plants cultivated on organic 
Table 2. Plant height and mass of plant depending on the covering and type of straw (mean for 2010-2012)

\begin{tabular}{lcccccc}
\hline \multirow{2}{*}{ Type of straw } & \multicolumn{3}{c}{ Plant height $(\mathrm{cm})$} & \multicolumn{3}{c}{ Mass of plant $(\mathrm{g})$} \\
\cline { 2 - 7 } Control & not covered & under covers & mean & not covered & under covers & mean \\
Rye & 58.3 & 56.4 & 57.4 & 274.3 & 394.7 & 334.5 \\
Corn & 57.5 & 60.0 & 58.7 & 302.6 & 383.6 & 343.1 \\
Rape & 57.9 & 67.8 & 62.9 & 288.2 & 485.1 & 386.6 \\
Buckwheat & 60.7 & 66.5 & 63.6 & 298.8 & 550.6 & 424.7 \\
\hline Mean & 59.1 & 63.6 & 61.4 & 359.4 & 489.5 & 424.4 \\
\hline LSD $\alpha=0.05$ for: & 58.7 & 62.9 & 60.8 & 304.7 & 460.7 & 382.7 \\
covering & & & & & & 60.5 \\
type of straw & & & 5.3 & & & 102.4 \\
covering $\times$ type of straw & & & & & & \\
\hline
\end{tabular}

mulch with wheat straw and sawdust were higher by 5.54 and $7.72 \mathrm{~cm}$ on average compared to plants from the control without mulch. These results concurred with those of Makus et al. (1994), who observed that plant height was significantly affected by different mulching materials. According to the authors, the application of mulch increased plant height due to higher soil moisture conservation and reduced water stress. In turn, Gordon et al. (2008) found that plants cultivated on mulched soil were higher than plants from the control plot; however, treatments consisting of mulch and row covers produced significantly higher plants than treatments without row covers.

A higher soil and air temperature under covers provides better conditions for plants immediately after planting and allows them to produce a higher mass of above-ground parts (Wadas et al. 2009), which was confirmed in the present study (Tab. 2). The mass of plants cultivated under polypropylene fibre was higher on average by $156.0 \mathrm{~g}$ compared to the plants without covers.

The present research showed significant differences in the mass of plants cultivated on the varied types of straw. It was found that irrespective of covering, soil mulching with rape and buckwheat straw had the most favourable influence on the growth of plants. The difference between these straws and the non-mulched control amounted to $90.2 \mathrm{~g}$ and $89.9 \mathrm{~g}$, respectively. The interaction between the covering and the type of straw applied to soil mulching on the plant mass was not statistically confirmed (Tab. 2). In a study by Ibarra et al. (2001), melon plants from mulched and covered plots were characterised by significantly higher biomass compared to plants from the control object without mulch or covers.

The assimilation leaf area depends of the genetic features of the species and cultivar, the density of the plants, their wholesomeness, climatic conditions and agro-technology treatments

Table 3. Assimilation leaf area and leaf area index (LAI) depending on the covering and the type of straw (mean for 2010-2012)

\begin{tabular}{lcccccc}
\hline \multirow{2}{*}{ Type of straw } & \multicolumn{3}{c}{ Assimilation leaf area $\left(\mathrm{m}^{2}\right)$} & \multicolumn{3}{c}{ Leaf area index } \\
\cline { 2 - 7 } Control & not covered & under covers & mean & not covered & under covers & mean \\
Rye & 1.20 & 1.53 & 1.37 & 5.02 & 6.38 & 5.70 \\
Corn & 1.42 & 1.49 & 1.45 & 5.91 & 6.20 & 6.06 \\
Rape & 1.30 & 2.12 & 1.71 & 5.41 & 8.85 & 7.13 \\
Buckwheat & 1.34 & 2.44 & 1.89 & 5.58 & 10.18 & 7.88 \\
\hline Mean & 1.74 & 1.77 & 1.76 & 7.26 & 7.38 & 7.32 \\
\hline LSD $\alpha=0.05$ for: & 1.40 & 1.87 & 1.64 & 5.83 & 7.80 & 6.82 \\
covering & & & & & & 0.96 \\
type of straw & & & 0.23 & & & 1.77 \\
covering $\times$ type of straw & & & 0.43 & & & n.s. \\
\hline
\end{tabular}


Table 4. Assimilation leaf area and leaf area index (LAI) depending on the type of straw in the successive years of the study

\begin{tabular}{lcccccc}
\hline \multirow{2}{*}{ Type of straw } & \multicolumn{3}{c}{ Assimilation leaf area $\left(\mathrm{m}^{2}\right)$} & \multicolumn{3}{c}{ Leaf area index } \\
\cline { 2 - 7 } & 2010 & 2011 & 2012 & 2010 & 2011 & 2012 \\
\hline Control & 1.37 & 1.76 & 0.98 & 5.72 & 7.31 & 4.06 \\
Rye & 1.44 & 1.87 & 1.05 & 6.01 & 7.80 & 4.36 \\
Corn & 1.33 & 2.04 & 1.76 & 5.55 & 8.50 & 7.34 \\
Rape & 1.78 & 2.08 & 1.82 & 7.41 & 8.66 & 7.58 \\
Buckwheat & 1.34 & 1.82 & 2.11 & 5.58 & 7.58 & 8.80 \\
\hline LSD $\alpha=0.05$ for: & & & & & & 3.07 \\
years $\times$ type of straw & & & & & & \\
\hline
\end{tabular}

(Kołodziejczyk 2012). However, according to many authors leaf area development depends more strongly on the air temperature. Earlier plant growth as a result of covering allows for higher solar radiation interception and a rapid increase in assimilation leaf area (Soltani et al. 1995, Ibarra et al. 2001, Wadas and Kosterna 2007, Olle and Bender 2010), which was confirmed in the present study (Tab. 3). According to Gimenez et al. (2002), the transmission of photoactive radiation through polypropylene fibre cover varied from 85 to $65 \%$, depending on dust accumulation on the cover and water vapour condensation on the inner surface of the cover. The reduced irradiance under the covers might have been compensated by the greater leaf area index of the plants, the increased air and soil temperature under the covers, and by improved light distribution within the protected canopy, allowing crop growth and development. In the present study, the application of polypropylene fibre covers significantly influenced the size of the assimilation leaf area. The assimilation leaf area of covered plants was higher by $34 \%$ on average compared to the plants cultivated in plots without covers. More favourable conditions under covers also increased the leaf area index (LAI), which describes the growth of the plants. This study showed that the LAI value of plants cultivated under polypropylene fibre was almost 1.5 times higher compared to the plants cultivated without covers (Tab. 3). According to many authors, a higher LAI value could cause an increase in yield and improve its quality (Gordon et al. 1997, Gimenez et al. 2002, Tiedong Liu et al. 2012). A higher assimilation leaf area and LAI value in the cultivation of cabbage, beet, spinach and lettuce under covers was found in the study by Gimenez et al. (2002). According to these authors, LAI has been traditionally considered an appropriate index to characterise the interception of radiation in many crops. The larger
LAI and consequently greater relative interception of incoming photoactive radiation as well as the higher soil temperature appear to have more than compensated for the reduction of photoactive radiation caused by the covers.

The present study showed that irrespective of covering, plants cultivated on the mulched soil were characterised by higher a assimilation leaf area and LAI value compared to the plants cultivated in the non-mulched control. During the three study years, a significantly higher assimilation leaf area and LAI value were found for plants cultivated in plots mulched with rape straw compared to rye straw and the control without straw. The differences for assimilation leaf area amounted to $0.52 \mathrm{~m}^{2}$ and $0.44 \mathrm{~m}^{2}$ on average and 2.18 and 1.82 for LAI, respectively (Tab. 3).

The effect of the kind of straw on the assimilation leaf area and LAI value depended on the weather conditions (Tab. 4). The highest differences were observed in 2012. The plants cultivated on the mulch with corn, rape and buckwheat straw had significantly higher assimilation leaf areas and LAI values than those grown in the control plot without soil mulching. It was also found that cultivation in objects mulched with rape and buckwheat straw contributed to an increase in the investigated index compared to rye straw. In the study by Nguyen et al. (2013), soil mulching with compost contributed only to a slight and not statistically confirmed increase in the LAI value compared to plants without compost. According to Blanchart et al. (2006), during the mineralisation process of the mulch, small amounts of nutrients become available for plants, which could be the reason for better plant development. However, it is not a sufficient supply of plant nutrients.

Specific leaf area depends not only on the genotype, but also can be modified by weather conditions and factors affecting the plant during the 
Table 5. Specific leaf area, SLA $\left(\mathrm{m}^{2} \mathrm{~kg}^{-1}\right)$ depending on the covering and the type of straw (mean for 2010-2012)

\begin{tabular}{lccc}
\hline Type of straw & Not covered & Under covers & Mean \\
\hline Control & 10.63 & 10.63 & 10.63 \\
Rye & 11.70 & 10.65 & 11.18 \\
Corn & 10.92 & 11.40 & 11.16 \\
Rape & 11.12 & 11.37 & 11.25 \\
Buckwheat & 11.58 & 9.95 & 10.77 \\
\hline Mean & 11.19 & 10.80 & 10.99 \\
\hline
\end{tabular}

$\mathrm{LSD} \alpha=0.05$ for: covering $=$ n.s.; type of straw $=0.58$; covering $\times$ type of straw $=0.99$

growing period (Amanullah et al. 2007, Wadas and Kosterna 2007, Milla et al. 2008).

The study results indicated a significant influence of the interaction between the covering and the type of straw applied to soil mulching on the SLA value (Tab. 5). In the cultivation without covers, the SLA value was higher by $1.07 \mathrm{~m}^{2}$ $\mathrm{kg}^{-1}$ on average with the application of rye straw compared to the non-mulched control. In the plots covered with polypropylene fibre, a higher SLA value characterised plants cultivated on the corn and rape mulches compared to buckwheat straw. The differences amounted to 1.45 and $1.42 \mathrm{~m}^{2} \mathrm{~kg}^{-1}$, respectively. In a study by Soltani et al. (1995), plants cultivated on mulched soil and simultaneously covered indicated higher SLA values compared to control plots without mulching or covers. In turn, in the study by Ibarra et al. (2001), the SLA value in the mulched plots that were covered for only 10 days was lower than in the control. Longer plant covering (20 and 32 days after sowing) contributed to slightly increased SLA, but the differences were not statistically confirmed.

Weather conditions significantly differentiated yield level on the successive kinds of straw (Fig. 3). In 2010, a higher yield was obtained on the mulch with buckwheat straw compared with the non-mulched control. In 2011, a higher yield was achieved from plots mulched with rye and corn straw. In turn, in 2012 corn straw was the most favourable for tomato cultivation. Similarly, in the study by Sinkevičienè et al. (2009), the yield of vegetables depended on the kind of mulch applied to soil mulching. The authors found that yields of

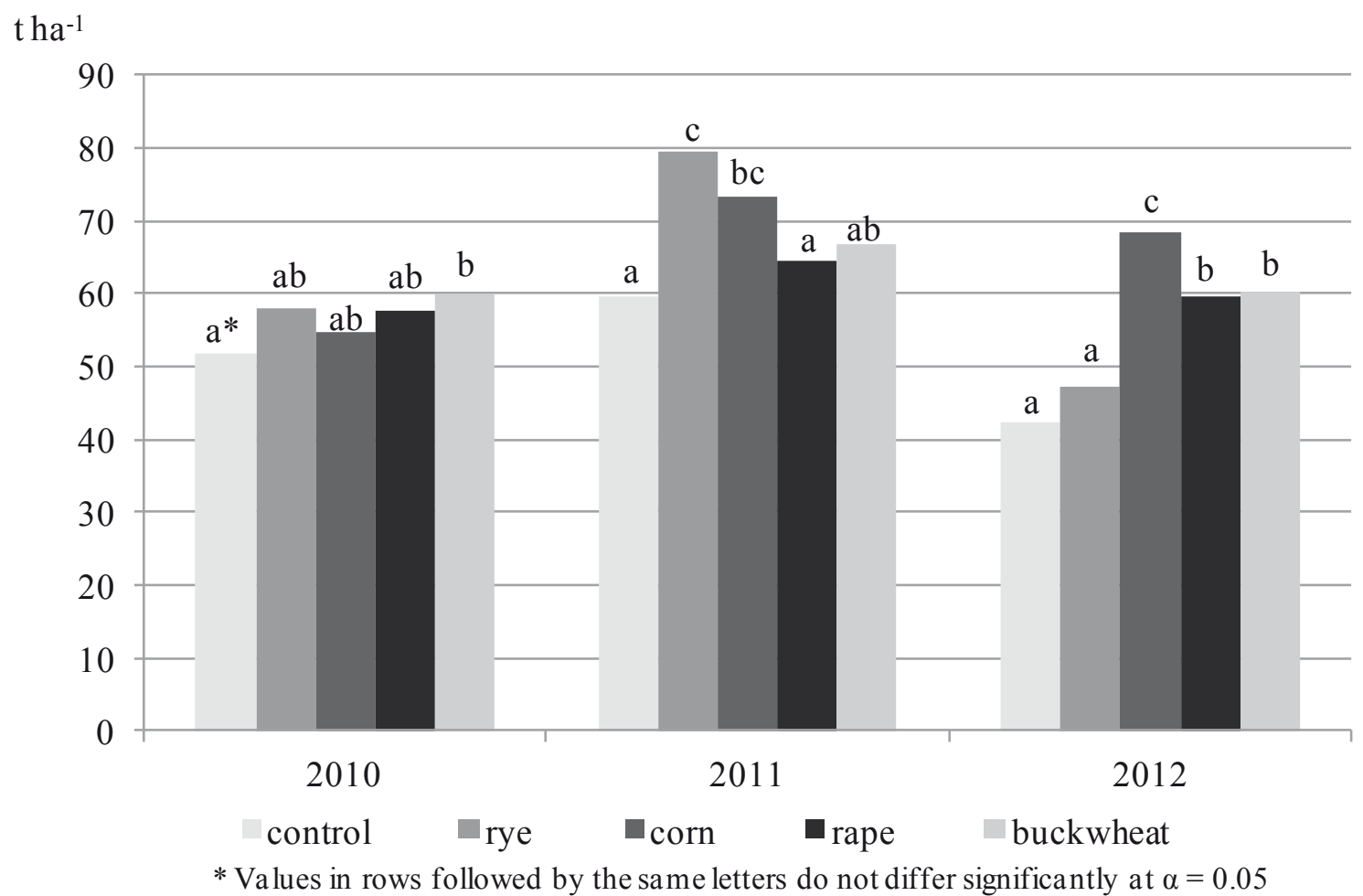

Figure 3. Tomato fruit yield $\left(\mathrm{t} \mathrm{ha}^{-1}\right)$ depending on type of straw in the successive years of the study 


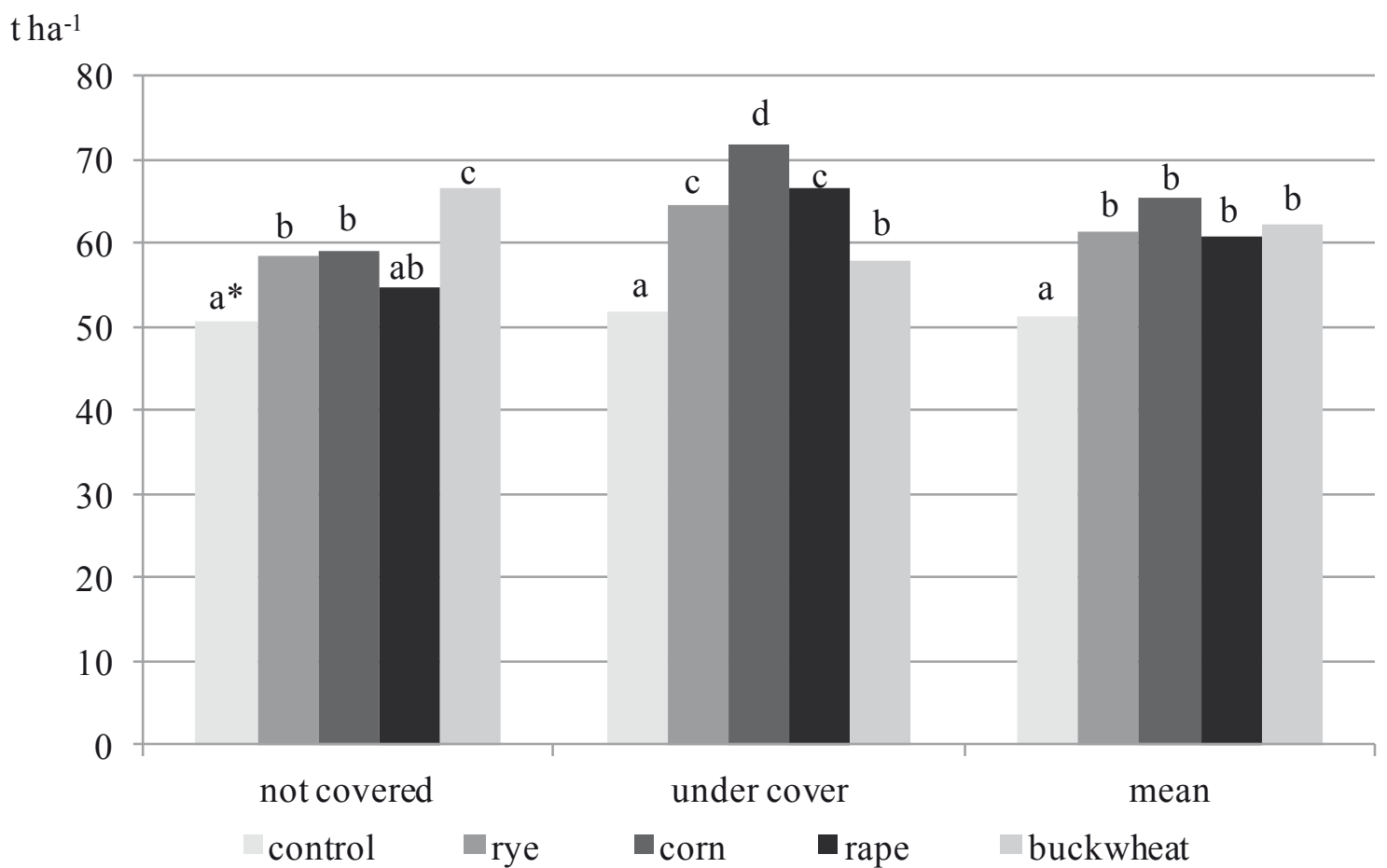

* Values in rows followed by the same letters do not differ significantly at $\alpha=0.05$

Figure 4. Tomato fruit yield ( $\mathrm{t} \mathrm{ha}^{-1}$ ) depending on the covering and type of straw (mean for 2010-2012)

vegetables from plots mulched with grass were the highest, while those from straw and peat substrate mulch were similar; however, sawdust was less effective as mulch. In the studies by Samaila et al. (2011), soil mulching significantly increased the total yield of tomato fruits compared with nonmulched plots. However, the authors did not find significant differences in the yield level between particular kinds of mulch.

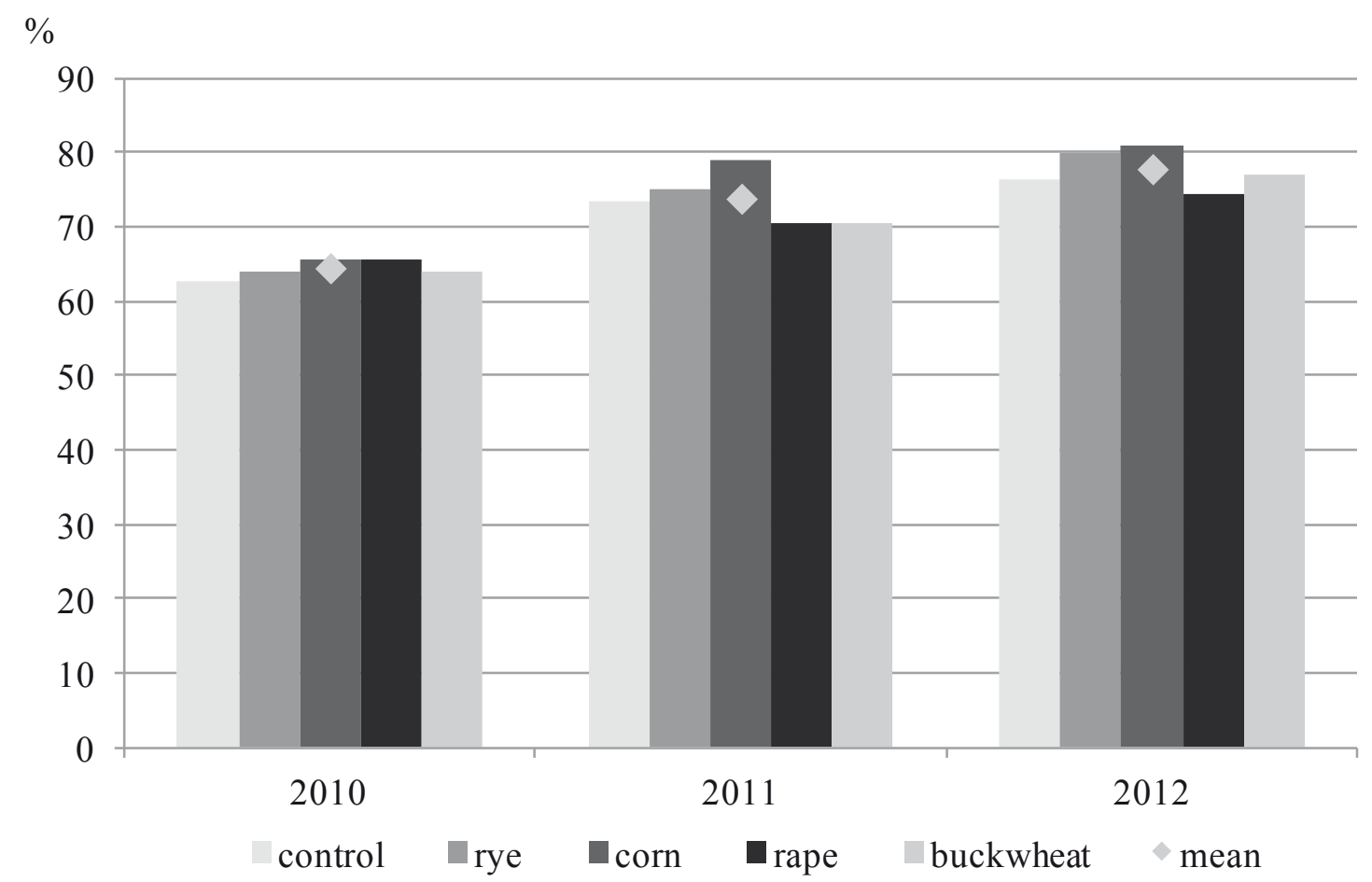

Figure 5. Share of marketable yield in the total yield (\%) depending on type of straw in the successive years of the study 
The application of polypropylene fibre improved the growth and development conditions of plants and as a result increased the yield of tomato fruit by $4.64 \mathrm{t} \mathrm{ha}^{-1}$ on average (Fig. 4). The study results showed a significant influence of the interaction between plant covering and the type of straw on the yield level. In cultivation without plant covering, a significantly highest yield of fruits was found in plots mulched with buckwheat straw. It was also found that the application of rye and corn straw increased yield compared with the non-mulched control. The differences amounted to 7.80 and $8.52 \mathrm{t} \mathrm{ha}^{-1}$, respectively. In the combination under polypropylene fibre, the highest yield was achieved on the mulch with corn straw. The yield from the plots mulched with the remaining kinds of straw was significantly higher than from the control. Soil mulching with rye and rape straw increased yield compared to buckwheat straw. Similarly in the study by Gordon et al. (2008), early marketable yield of squash was lowest from plants grown on bare soil with a row cover followed by bare soil alone. The highest early marketable yield was obtained from the combined cultivation of black mulch with a row cover. In studies by Błażewicz-Woźniak (2010), soil mulching with PP50 black non-woven fabric and, to a slightly lesser extent, black PE film, caused an increase of the total and marketable yield of fennel and had a favourable effect on its structure. The lowest total yield of bulbs with the highest share of non-marketable yield was obtained with plant covering with PP17 non-woven fabric.

Weather conditions in the study years influenced not only the total yield of tomato but also the percentage share of marketable yield in the total yield. The highest and lowest shares of marketable yield in the total yield were found in 2012 and 2010, respectively. In 2010, heavy rainfall coupled with high air temperatures contributed to the development of fungal diseases on plants and fruits, which decreased the marketable yield (Fig. 5).

Irrespective of the cultivation method, the share of marketable yield of the total yield of tomato amounted to $73.24 \%$ in uncovered plots and $70.82 \%$ under covers. In the uncovered combination, a lower share of marketable yield of the total yield was found in the plots with rape straw compared to the remaining straw mulches. In turn, a lower share of marketable yield under covers was obtained in the control plot without mulch. The highest share of marketable yield was achieved in plots with corn straw (Fig. 6).

\section{CONCLUSIONS}

1. The application of polypropylene fibre covers increased soil temperature.

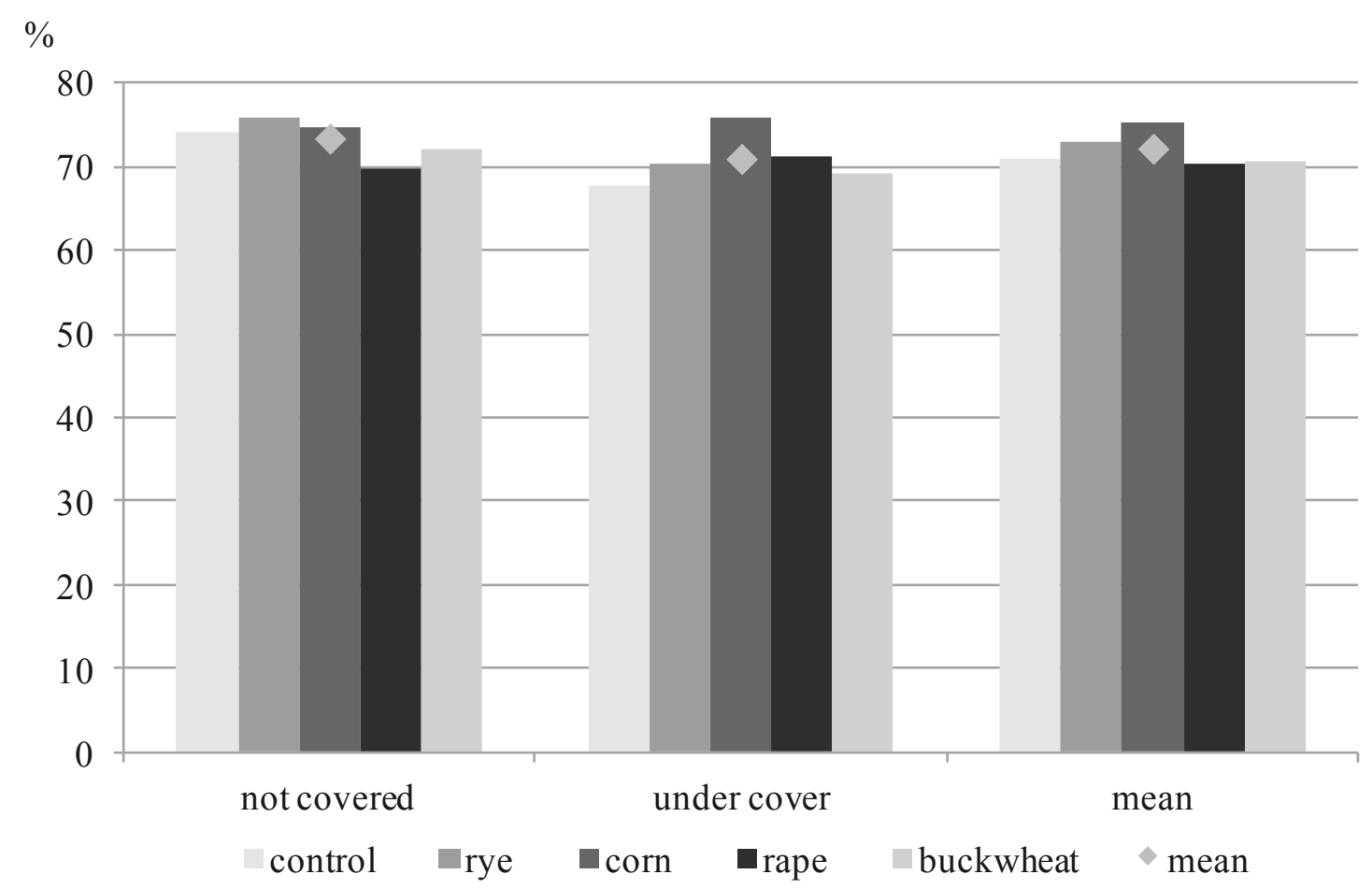

Figure 6. Share of marketable yield in the total yield (\%) depending on the covering and type of straw (mean for 20102012) 
2. Soil mulching, irrespective of the type of straw applied, contributed to slower soil warming compared to the control plot without mulch.

3. A higher soil and air temperature under covers provided better conditions for the faster growth and development of plants and increased assimilation leaf area and LAI values; however, it had no influence on the SLA value.

4. Soil mulching with straw resulted in greater aboveground plant biomass and higher physiological parameters compared with nonmulched plots, both in the cultivation without covers and with polypropylene fibre covers.

5. Simultaneous plant covering with polypropylene fibre and soil mulching with straw contributed to a higher total yield, but had no influence on the share of marketable yield in the total yield of fruits.

\section{ACKNOWLEDGEMENTS}

The research was supported by the Polish Ministry of Science and Higher Education as part of the statutory activities of the Department of Vegetable Crops of the Siedlce University of Natural Sciences and Humanities.

\section{REFERENCES}

Amanullah, Hassan M.J., Nawab K., Ali A., 2007. Response of specific leaf area (SLA), leaf area index (LAI) and leaf area ratio (LAR) of maize (Zea mays L.) to plant density, rate and timing of nitrogen application. World Appl. Sci. J. 2(3): 235-243.

Awal M.A., Khan M.A.H., 2000. Mulch induced ecophysiological growth and yield of maize. Pak. J. Biol. Sci. 3(1): 61-64.

Blanchart E., Villenave C., Viallatoux A., Barthës B., Girardin C., Azontonde A., Fellera C., 2006. Long-term effect of a legume cover crop (Mucuna pruriens var. utilis) on the communities of soil macrofauna and nematofauna, under maize cultivation, in southern Benin. Eur. J. Soil Biol. 42: 136-144.

BŁażeWiCZ-Woźniak M., 2010. Effect of soil and plant covering and sowing time on the yield of fennel bulbs grown from sowing directly in the field. Folia Hort. 22(2): 59-66.

Bond W., Grundy A.C., 2001. Non-chemical weed management in organic farming systems. Weed Res. 41: 383-405.

Chakraborty D., Nagarajan S., Aggarmal P., Gupta V.K., Tomar R.K., Garg R.N., Sahoo R.N., Sarkar A., Chopra U.K., Sundara Sarma K., Karla N., 2008. Effect of mulching on soil and plant water status, and the growth and yield of wheat (Triticum aestivum L.) in a semi-arid environment. Agric. Water Man. 95: 1323-1334.

Dahiya R., Ingwersen J., Streck T., 2007. The effect of mulching and tillage on the water and temperature regimes of a loess soil: Experimental findings and modeling. Soil Tillage Res. 96(1): 52-63.

Gimenez C., Отto R.F., Castilla N., 2002. Productivity of leaf and root vegetable crop under direct cover. Sci. Hort. 94: 1-11.

Gordon G.G., Wheeler G.F., Stewart T.R., Brown J.E., Vinson E., Woods F.M., 2008. Plastic mulches and row covers on growth and production of summer squash. Int. J. Veg. Sci. 14(4): 322-338.

Gordon R., Brown D.M., Dixon M.A., 1997. Estimating potato leaf area index for specific cultivars. Potato Res. 40: 251-266.

Gruber S., Acharya D., Claupein W., 2008. Wood chips used for weed control in Organic Farming. J. Plant Dis. Protect. 21: 395-400.

Hamouz K., Lachman J., Dvořák P., Trnková E., 2006. Influence of non-woven fleece on the yield formation of early potatoes. Plant Soil Environ. 52(7): 289-294.

Ibarra L., Flores J., Díaz-Pérez J.C., 2001. Growth and yield of muskmelon in response to plastic mulch and row covers. Sci. Hort. 87(1-2): 139-145.

Kęsik T., Maskalaniec T., 2005. Effect of soil mulching on air and soil temperature in strawberry field. Acta Agroph. 6(1): 117-124.

KoŁodzIEJCZyK M., 2012. Effect of the degree and timing of the simulated reduction of plants assimilation area on the yielding of potato. Fragm. Agron. 29(3): 8187.

Makus D.J., Tiwarl S.C., Pearson H.A., Haywood J.D., TiRKS A.E., 1994. Okra introduction with pine straw mulch. Agroforestry Sys. 27(2): 121-127.

Milla R., Reich P.B., Ninnemets Ü., Castro-Díez P., 2008. Environmental and developmental controls on specific leaf area are little modified by leaf allometry. Functional Ecol. 22: 565-576.

Moreno D.A., Víllora G., Hernández J., Castilla N., Monreal L.R., 2002. Yield and chemical composition of Chinese cabbage in relation to thermal regime as influenced by row covers. J. Amer. Soc. Hort. Sci. 127(3): 343-348.

Nguyen T.T., Fuentes S., Marschner P., 2013. Effect of incorporated or mulched compost on leaf nutrient concentrations and performance of Vitis vinifera cv. Merlot. JSSPN 13(2): 485-497.

Olasantan F.O., 1999. Effect of time of mulching on soil temperature and moisture regime and emergence, growth and yield of white yam in western Nigena. Soil Tillage Res. 50: 215-221.

Olle M., Bender I., 2010. The effect of non-woven fleece on the yield and production characteristics of vegetables. Agraarteadus J. Agric. Sci. 1: 24-29.

Roztropowicz S., 1999. Methodics of observation, measurements and sample take in agricultural 
experiments with potato. Plant Breed. Acclim. Inst., Jadwisin.

SAJid M., Hussain I., Khan I.A., Rab A., JAN I., FAZAL-IWAHID, SHAH S.T., 2013. Influence of organic mulches on growth and yield components of pea's cultivars. Greener J. Agric. Sci. 3(8): 652-657.

Samaila A.A., Amans E.B., Abubakar I.U., Babaji B.A., 2011. Yield and fruit quality of tomato (Lycopersicon esculentum Mill) as influenced by mulching, nitrogen and irrigation interval. Int. Res. J. Agric. Sci. Soil Sci. 1(3): 90-95.

Schonbeck M.W., Evanylo G.K., 1998. Effects of mulches on soil properties and tomato production I. Soil temperature, soil moisture and marketable yield. J. Sustain. Agric. 13(1): 55-81.

Sinkevičienė A., Jodaugienė D., Pupalienė R., Urbonienė M., 2009. The influence of organic mulches on soil properties and crop yield. Agron. Res. 7(1): 485-491.

Soltani N., Anderson LaMar J., Hamson A.R., 1995. Growth analysis of watermelon plants grown with mulches and row covers. J. Amer. Soc. Hort. Sci. 120(6): 1001-1009.
Teasdale J.R., Abdul-Baki A.A., 1997. Growth analysis of tomatoes in black polyethylene and hairy vetch production systems. HortSci. 32(4): 659-663.

Tiedong Liu, Fengbin Song, Shengqun Liu, Xiancan ZHU, 2012. Light interception and radiation use efficiency response to narrow-wide row planting patterns in maize. AJCS 6(3): 506-513.

WAdAs W., Kosterna E., 2007. Effect of perforated foil and polypropylene fibre covers on assimilation leaf area of early potato cultivars. Plant Soil Environ. 53(7): 299-305.

Wadas W., Kosterna E., Kurowska A., 2009. Effect of perforated foil and polypropylene fibre covers on growth of early potato cultivars. Plant Soil Environ. 55(1): 33-41.

WinIARSKA S., 2006. The effect of methods of plantation establishment on the growth and development of artichoke (Cynara scolymus L.). Acta Agroph. 8(3): 745-753.

WRB FAO, 1998. World Reference Base For Soil Resources World Soil Resource. Reports FAO, ISRIC, ISSS, Rome.

Received March 13, 2014; accepted July 8, 2014 